\title{
Flexural Capacity of Rattan Cane Reinforced Concrete Beams
}

\author{
Sjamsuddin Kaaba ${ }^{1 *}$, Mufti Amir Sultan ${ }^{2}$, Sudarman Samad ${ }^{3}$ \\ ${ }^{1}$ Master Degree Program, Department of Civil Engineering, Universitas Khairun, Indonesia \\ ${ }^{2}$ Department of Civil Engineering, Faculty of Engineering, Universitas Khairun, Ternate, Indonesia \\ ${ }^{3}$ Department of Architecture, Faculty of Engineering, Universitas Khairun, Ternate, Indonesia
}

\begin{abstract}
To overcome the dependence on the use of reinforcing steel in concrete, alternative materials are used as reinforcement that is easy and cheap to obtain the resistant of corrosion namely rattan rods. With this material the natural resources can be utilized optimally. This research uses rattan as reinforcement for concrete beams. The test is carried out using a two-point loading method, used 4 types of beams, namely 2 rattan reinforcement beam $\left(\mathrm{BR}_{2}\right), 3$ rattan reinforcement $\left(\mathrm{BR}_{3}\right), 4$ rattan reinforcement $\left(\mathrm{BR}_{4}\right)$ and 2 steel reinforcement $\left(\mathrm{BS}_{2}\right)$ as control beams. The test results show that the addition of 2 times the amount of rattan reinforcement resulted in an increase in flexural capacity of $48.51 \%$. The flexural capacity of rattanreinforced beams is lower than the flexural capacity of steel-reinforced beams by $10 \%$, so the use of rattan as reinforcement in non-structural construction.
\end{abstract}

Keyword: Rattan, Reinforced, Concrete Beams

\section{Introduction}

Steel-reinforced concrete is a construction material that is commonly used in building structures, where the compressive strength of concrete and tensile strength of steel is a complementary combination. However, the use of steel as reinforcement still poses several obstacles, including the higher price. The increasingly high price of steel reinforcement will be very burdensome for the community, especially the economically weak community, in an effort to meet their primary needs, namely in the form of decent housing.

Therefore, it is necessary to seek an alternative substitute for steel reinforcement in concrete [1-2]. The alternative as a substitute for the reinforcement is rattan cane. Rattan cane are a renewable natural resource that can be obtained easily, cheaply, and is resistant to corrosion.

Bamboo and rattan can be used as an alternative to steel in low-cost lightweight construction for areas where steel reinforcement is difficult to obtain [2]. The use of rattan as reinforcement can increase the load carrying capacity of beams that have the same dimensions. At peak load, Reinforced Concrete Beams of Single Rattan cane crumble under the load followed by the breaking of Rattan cane whereas Steel does not break but loses its elasticity [3]. The use of bamboo rods as reinforcement is suitable for structures with light loads, while for rattan, more reinforcement treatment is needed to increase interfacial bonding and load carrying capacity [4]. Rattan cane can be used as reinforcement in concrete blocks [5-6].
It is important to do this research by utilizing local rattan cane from the North Maluku region.

\section{Materials and method}

\subsection{Rattan cane}

The Rattan Cane used for this study was obtained from Goal Village, Halmahera Barat Regency, Indonesia. The rattan cane was $10 \mathrm{~mm}$ in diameter and it was cut into $500 \mathrm{~mm}$ long as required for the research work.

\subsection{Coarse and fine aggregate}

Coarse Aggregate used for this research work was 12 $\mathrm{mm}$ size. It was sourced from a quarry Kali Oba in Halmahera Island. Coarse aggregate test based on SNI [7-10].

The sand used for this research work was sourced from quarry Kalumata, Ternate Island, Indonesia. Fine aggregate test based on SNI [7-8] [11]. Quarry of coarse aggregate and fine aggregate as shown in Fig 1.

\subsection{Steel reinforcement}

The reinforcement of size $10 \mathrm{~mm}$ was obtained in Ternate, Indonesia. The reinforcement was cut into 500 mm long.

\footnotetext{
* Corresponding author : sjamsuddin654@gmail.com
} 


\subsection{Cement}

The cement used was Portland Cement. It was sourced from Ternate, and it conformed to the requirements of SNI [12].

\subsection{Concrete Mix Design}

The cross section of beam specimen was $100 \times 150 \mathrm{~mm}$ with the total length of $600 \mathrm{~mm}$. All specimens were precracked by a notch of $20 \mathrm{~mm}$ along the width of beams at the span center to localize the crack when loading. Un-continuous D10 steel reinforcement were applied in upper side of the beam with the space of $20 \mathrm{~mm}$ between them (Fig. 2) to avoid concrete failure or cracks on the shear span [13].

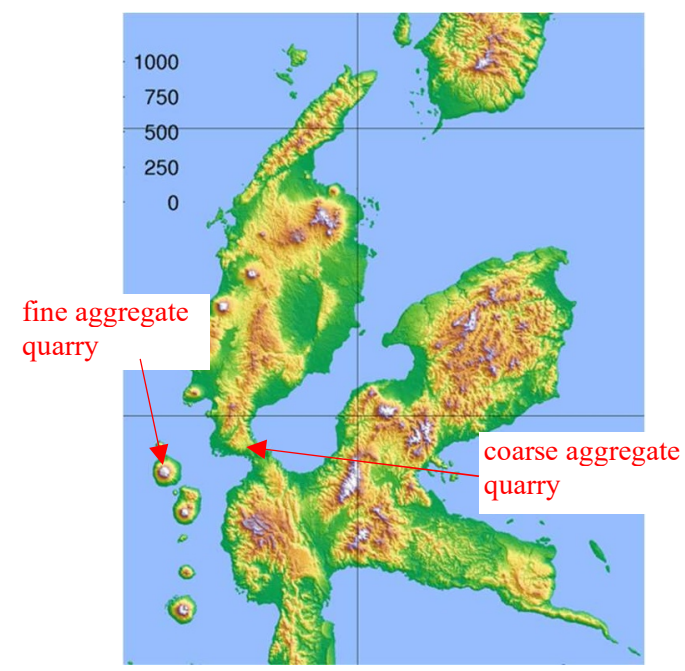

Fig. 1. Coarse and fine aggregate quarry

\subsection{Specimen}

Concrete beams were treated for 28 days. Cylindrical specimens measuring $150 \times 300 \mathrm{~mm}$ were prepared to determine the material properties of concrete. Rattan reinforcement is placed at the bottom of the beam, the variations of reinforcement are 2 pieces with the symbol $\mathrm{BR} 1$, and 3 pieces with the symbol BR2, and 4 pieces with the symbol BR3. Beams with 2 pieces of steel reinforcement as control beams (BK), the details of the test object are shown in Fig. 2 and table 1.

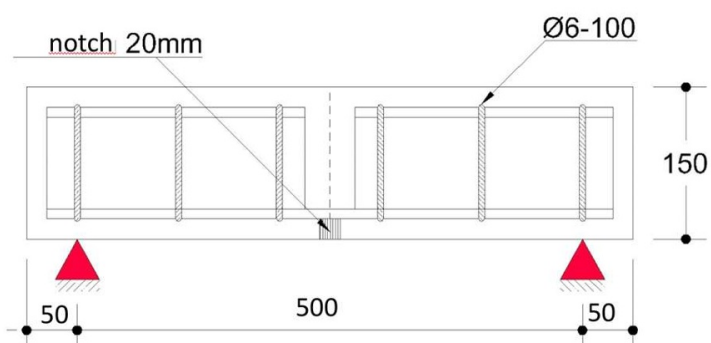

Fig. 2. Details of specimens
Table 1. Summary of specimens

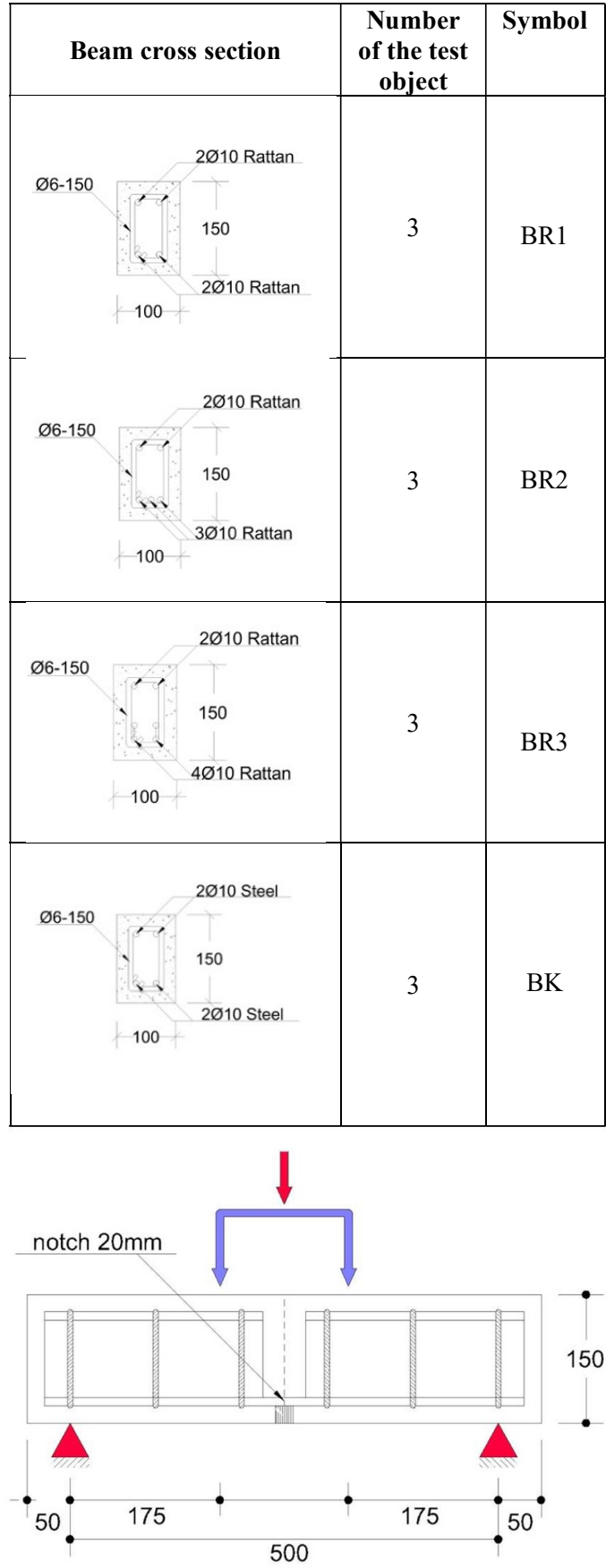

Fig. 3. Test set up

\subsection{Test set up}

The test object is placed on 2 supports. The effective span of the beam is $500 \mathrm{~mm}$. The beam is tested for bending under two-point loading. The load is applied to the beams at a distance of $175 \mathrm{~mm}$ from each support. Loads are applied to the beam until the first crack is visible and the appropriate deflection is recorded until the final failure of the beam is achieved. The test setup is shown in the Fig. 3 


\section{Result and Siscussion}

\subsection{Maximum Moment}

The calculation of the maximum moment of the results of this test uses the concept of simple beam statics with a uniform load and a concentrated load of $\mathrm{p} / 2$ in one third of the span. From the maximum load obtained during the test, the bending moment uses the eq. 1 .

$$
M u=0.0011+0.1 P
$$

The results of the calculation of the maximum moment of the test are presented in table 2

Table 2. The result of the calculation of the maximum moment of the test

\begin{tabular}{|c|c|c|c|}
\hline $\begin{array}{c}\text { Test } \\
\text { Object }\end{array}$ & $\begin{array}{l}\text { Maximum } \\
\text { load } \\
\text { (ton) }\end{array}$ & $\begin{array}{c}\text { Maximum } \\
\text { Moment } \\
\text { (ton.m) }\end{array}$ & $\begin{array}{c}\text { Average } \\
\text { maximum } \\
\text { moment } \\
\text { (ton.m) }\end{array}$ \\
\hline BR2-1 & 1.563 & 0.157 & \multirow{3}{*}{0.162} \\
\hline BR2-2 & 1.650 & 0.166 & \\
\hline BR2-3 & 1.625 & 0.164 & \\
\hline BR3-1 & 1.625 & 0.164 & \multirow{3}{*}{0.165} \\
\hline BR3-2 & 1.500 & 0.151 & \\
\hline BR3-3 & 1.800 & 0.181 & \\
\hline BR4-1 & 2.500 & 0.251 & \multirow{3}{*}{0.241} \\
\hline BR4-2 & 2.450 & 0.246 & \\
\hline BR4-3 & 2.250 & 0.226 & \\
\hline BS2-1 & 2.150 & 0.216 & \multirow{3}{*}{0.283} \\
\hline BS2-2 & 3.250 & 0.326 & \\
\hline BS2-3 & 3.050 & 0.306 & \\
\hline
\end{tabular}

Based on table 2, it can be explained that the addition of the amount of rattan as reinforcement can increase the load capacity. However, it is lower than steel-reinforced beams by $14.7 \%$.

\subsection{Flexural Capacity}

Calculation of flexural capacity using the equation

$$
f=\frac{M \cdot y}{I}
$$

Where :

$$
\begin{array}{ll}
f & =\text { flexural capacity }\left(\text { ton } / \mathrm{m}^{2}\right) \\
M & =\text { Maximum moment }(\text { ton.m) } \\
I & =\text { Inersia moment }\left(\mathrm{m}^{4}\right)
\end{array}
$$

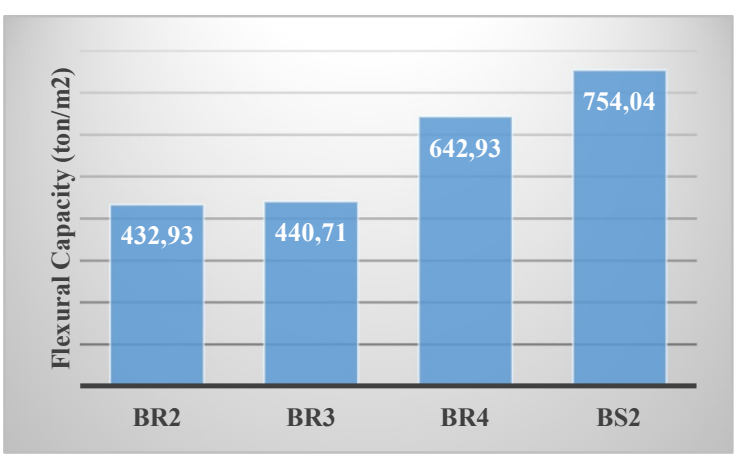

Fig. 4. Maximum flexural capacity of rattan and steel reinforced concrete beams

Based on Figure 4 it can be shown that the addition of the amount of rattan increases the flexural capacity of the concrete beam. The flexural capacity of BR2, BR3 and BR4 beams are $423.93 \mathrm{t} / \mathrm{m} 2,440.71 \mathrm{t} / \mathrm{m} 2$ and $642.93 \mathrm{t} / \mathrm{m} 2$, respectively. However, the flexural capacity of rattan-reinforced beams of 4 reinforcement is still $10 \%$ lower than that of steel-reinforced beams.

\section{Conclusion}

From the research and calculations that has been done the author can give the following conclusions:

1. The flexural capacity of the rattan-reinforced beam increases with the addition of the rattan reinforcement.

2. The addition of 2 times the amount of rattan reinforcement resulted in an increase in flexural capacity of $48.51 \%$.

3. The flexural capacity of rattan-reinforced beams is lower than the flexural capacity of steel-reinforced beams by $10 \%$, so the use of rattan as reinforcement in non-structural construction.

\section{References}

[1] I. Wirantina Kustanrika, "Pemanfaatan Sumber Daya Alam Dengan Menggunakan Batang Rotan Sebagai Pengganti Tulangan Beton," in Seminar Nasional Sains dan Teknologi 2016, (2016), no. November, pp. 1-8.

[2] A. J. Olawale and A. S. Wasiu, "Structural Characteristic Of Bamboo and Rattan Cane Reinforced Concrete Struts," Phys. Rev. Res. Int., 3(4), pp. 602-611, (2013).

[3] I. O. Obilade and F. A. Olutoge, "Flexural Characteristics of Rattan Cane Reinforced Concrete Beams," Int. J. Eng. Sci., 3(6), pp. 38-42, (2014).

[4] A. P. Adewuyi, A. A. Otukoya, O. A. Olaniyi, and O. S. Olafusi, "Comparative Studies of Steel, Bamboo and Rattan as Reinforcing Bars in Concrete: Tensile and Flexural Characteristics," Open J. Civ. Eng., 5(2), pp. 228-238, (2015).

[5] M. A. Febrianto, "Perilaku Lentur Balok Beton Bertulang Dengan Tulangan Rotan dan Tulangan Besi Polos," J. Tek. Sipil dan Arsit., 2(2), pp. 134- 
146, (2016).

[6] N. Trisnawati, "Kapasitas Lentur Panel Bertulangan Rotan dengan Beton Mutu Tinggi Menggunakan Semen, Fly Ash dan Kapur," Din. Tek. Sipil Maj. Ilm. Tek. Sipil, 13(2), pp. 48-53, (2020).

[7] SNI 03-1968-1990, Metode Pengujian Tentang Analisis Saringan Agregat Halus dan Kasar. 1990.

[8] SNI 03-1971-1990, Metode Pengujian Kadar Air Agregat. (1990).

[9] SNI 2417, Cara Uji Keausan Agregat Dengan Mesin Abrasi Los Angeles. 2008.

[10] SNI 1969, Cara Uji Berat Jenis dan Penyerapan Air Agregat Kasar. (2008).

[11] SNI 1970, "Cara Uji Berat Jenis dan Penyerapan Air Agregat Halus," Badan Standar Nas. Indones., pp. 7-18, (2008).

[12] SNI 2049-2015, Standar Nasional Indonesia Semen portland. (2015).

[13] R. Djamaluddin, M. Amir Sultan, R. Irmawati, and H. Shinichi, "Bond Characteristics of GFRP Sheet on Strengthened Concrete Beams due to Flexural Loading," Int. J. Eng. Technol., vol. 7, no. 2, pp. 110-115, (2015). 